Editorial content

Open Access

\title{
Scientia Pharmaceutica, Autorenhinweise 2010
}

Sci Pharm. 2010; 78: 383-396

doi:10.3797/scipharm.aut-10-01

Die Zeitschrift Scientia Pharmaceutica (www.scipharm.at) erscheint vierteljährlich jeweils am Quartalsende und ist ein Medium zur Publikation von Originalarbeiten, Kurzmitteilungen und ausgewählten Übersichtsarbeiten aus allen wissenschaftlichen Disziplinen der Pharmazie und angrenzenden Gebieten sowie der pharmazeutischen Praxis.

Scientia Pharmaceutica wird in zahlreichen Datenbanken laufend indexiert; darunter auch: Chemical Abstracts (SciFinder), Scopus, Beilstein Database, International Pharmaceutical Abstracts, Natural Product Updates, CAB Abstracts, Chemlnform, Embase / Excerpta Medica, Index Pharmacus, EBSCO, etc.

Manuskripte in Deutsch oder Englisch können per E-Mail an office@scipharm.at eingereicht werden. Alternativ ist eine Einreichung in dreifacher Ausfertigung an die Schriftleitung - p/a Univ.-Prof. Dr. W. Kubelka, Department für Pharmakognosie, Universität Wien, Althanstraße 14, A-1090 Wien, Österreich - gemeinsam mit einer elektronischen Version in MS Word-Format auf Diskette oder CD-Rom möglich. Name, Anschrift, E-Mail-Adresse, Telefon- und Fax-Nummer des Korrespondenzautors sind in einem gesonderten Schreiben (cover letter) anzugeben. Es wird dringend empfohlen, das Manuskript mit Hilfe der MS Word-Vorlage zu erstellen - die aktuelle Version ist auf der Homepage verfügbar (www.scipharm.at/autoren). Der Eingang des Manuskriptes wird dem Korrespondenzautor per E-Mail bestätigt.

Die Schriftleitung behält sich vor, Arbeiten mit groben sprachlichen, formalen oder inhaltlichen Mängeln abzulehnen. Vor der Einreichung von Übersichtsarbeiten ist eine Zusammenfassung der Reaktion zu schicken. Es werden nur unveröffentlichte Arbeiten angenommen; sind Teilergebnisse bereits veröffentlicht, so sind diese korrekt zu zitieren und die entsprechenden Arbeiten beim Einreichen mitzuschicken.

Die eingelangten Manuskripte werden ausnahmslos einem Begutachtungsverfahren (peer review) unterzogen, das ein zugeteilter Redakteur mit Hilfe von externen Gutachtern leitet. Bei der Einreichung sollten 3-5 unabhängige und kompetente Gutachter vorgeschlagen werden (komplette Anschrift und E-Mail-Adressen sind erforderlich). Die endgültige Entscheidung obliegt der Schriftleitung.

Mit der Einreichung eines Manuskriptes bestätigt der Autor, die Erlaubnis seiner CoAutoren zu besitzen, folgende Abmachungen zu tätigen. Er bestätigt, in seinem Namen so wie im Namen der Co-Autoren, dass...

die eingereichte Arbeit weder in einer anderen Zeitschrift veröffentlicht wurde noch sich unter Begutachtung befindet, noch gegen Urheber- oder andere Rechte dritter verstößt;

er der einzige Autor ist / sie die einzigen Autoren sind und die Befugnis besitzt / besitzen, 
diese Abmachung einzugehen und Lizenzrechte der Österreichischen Apothekerverlagsges. m. b. H. zu gewähren;

die Arbeit weder rechtwidrig noch verleumderisch ist und die Veröffentlichung gegen keinerlei Verträge, Verschwiegenheitsabkommen oder Geheimsachen verstößt;

er / sie für die Vollständigkeit und Rechtschaffenheit des Artikels gesorgt hat / haben. Nach bestem Wissen und Gewissen des Autors / der Autoren so wie nach dem Stand der Wissenschaft sind die in dem Artikel getätigten Aussagen wahr und die genaue und sorgfältige Wiederholung der angegebenen Arbeitsvorschriften führt weder zu Verletzungen noch zu Krankheit;

die eingereichte Arbeit - sofern angenommen - unter den Creative Commons 3.0Lizenzbestimmungen (http://creativecommons.org/licenses/by/3.0/) veröffentlicht wird und der Österreichischen Apothekerverlagsges. m. b. H. lizenziert wird. Zusammengefasst bedeutet dies, dass der Autor / die Autoren das Copyright behalten und die Arbeit open access veröffentlicht wird: Es ist jedermann gestattet, das Werk zu vervielfältigen, zu verbreiten und öffentlich zugänglich zu machen; Abwandlungen bzw. Bearbeitungen des Inhaltes anzufertigen; kommerziell zu nutzen zu den folgenden Bedingungen: Sie müssen den Namen des Autors/Rechteinhabers in der von ihm festgelegten Weise nennen (zitieren) und im Falle einer Verbreitung müssen Sie anderen die Lizenzbedingungen, unter welche dieses Werk fällt, mitteilen. Jede der vorgenannten Bedingungen kann aufgehoben werden, sofern dies der Rechteinhaber einwilligt.

Es gibt keinerlei Gebühren oder Kosten, die dem Autor bzw. seiner Institution im Rahmen der Veröffentlichung eines Artikels anfallen. Die Onlineversion der Zeitschrift kann kostenlos gelesen werden; Informationen zum Abonnement der Druckversion sind online verfügbar: www.scipharm.at/bestellung.

\section{Manuskript-Checkliste}

$\square \quad$ Wurde das Manuskript entsprechend den Autorenrichtlinien, möglichst mit Hilfe der MS Word-Manuskriptvorlage erstellt?

$\square \quad$ Überprüfung auf Rechtschreibfehler? (Externe) Sprachkorrekturen?

$\square \quad$ Einzelne MS Word-Datei eingereicht? Alle Tabellen, Grafiken und Schemata im Hochformat und an der entsprechenden Stelle im Manuskript eingefügt?

$\square \quad$ Korrespondenzadresse (E-Mail, Postadresse, Telefon, Fax) ?

$\square \quad$ Vollständige Namen aller Autoren (kompletter Vor- und Nachname)?

$\square \quad$ Korrekte Formatierung der Zitate [z. B. 1, 3, 6-9]?

$\square \quad$ Begleitschreiben mit allen relevanten Informationen für die Schriftleitung?

$\square \quad$ Gutachtervorschläge inkl. E-Mail- und Postadresse?

Die folgenden Autorenhinweise sind wie ein Manuskript gestaltet und müssen genau befolgt werden. Alle relevanten Informationen bezüglich Formatierung sind grau hervorgehoben. Die Manuskripte werden bei der direkten Reproduktion auf etwa $70 \%$ der Originalgröße reduziert. 


\section{Titel der Arbeit \\ [Arial Black 18, fett, zentriert]}

\section{Wolfgang A. MOZART * ${ }^{1}$, Erwin SCHRÖDINGER ${ }^{2}$, Gregor MENDEL ${ }^{2}$, Joseph HAYDN ${ }^{1}$, Ludwig BOLTZMANN ${ }^{2}$ \\ [Arial 14, fett, zentriert, Nachnamen in Kapitälchen]}

${ }^{1}$ Institution, Universität, Straße Nr., PLZ, Ort, Land [Arial 10, Blocksatz]

${ }^{2}$ Institution, Universität, Straße Nr., PLZ, Ort, Land [Arial 10, Blocksatz]

* Korrespondenzautor. E-Mail(s): mail@mail.com (A. Author) [Arial 10, linksbündig]

Sci Pharm. 20XX; 7X: XXX-XXX doi:10.3797/scipharm.xxx

Veröffentlicht: TT. Monat $2010 \quad$ Eingelangt: TT. Monat 2010

Angenommen: TT. Monat 2010

Diese Arbeit ist online erhältlich unter: http://dx.doi.org/10.3797/scipharm.xxx

(C) Autor et al.; lizenziert von Österreichischer Apotheker-Verlagsgesellschaft m. b. H., Wien, Österreich.

Dies ist ein Open Access-Artikel, der unter den Bedingungen der Creative Commons 3.0-Lizenzbestimmungen (http://creativecommons.org/licenses/by/3.0/) vertrieben wird. Diese erlauben das Werk uneingeschränkt zu nutzen, zu vervielfältigen und zu verbreiten, sofern die Originalarbeit korrekt zitiert wird.

\section{Zusammenfassung [Arial 14, fett, Einzug links $1 \mathrm{~cm}$ ]}

Die Kernaussagen sollten in einem Absatz zusammengefasst werden. Arbeiten in Deutsch benötigen alternativ Titel und Zusammenfassung in Englischer Sprache (bei mangelnden Englischkenntnissen unterstützt die Schriftleitung. [Arial 12, Blocksatz, Einzug links und rechts $1 \mathrm{~cm}$ ]

\section{Schlagwörter [Arial 14, fett, links]}

Maximal 5 Schlagwörter, durch sog. Blickfangpunkte $(\bullet)$ getrennt. Keine Wörter aus dem Titel verwenden.

\section{Einführung [Arial 14, fett, links]}

Es wird empfohlen, das Manuskript in die Abschnitte "Zusammenfassung", "Schlagwörter", „Einleitung”, „Ergebnisse und Diskussion“, „Experimentelles”, „Danksagung“ (wenn nötig), „Zusatzmaterial“, „Ethische Stellungnahmen“ und „Literatur“ zu gliedern.

\section{Ergebnisse und Diskussion [Arial 14, fett, links]}

\section{Seitenformat [Arial 12, fett, kursiv, links]}

Manuskripte müssen auf A4 Papier (21,0 x 29,7 cm), Hochformat, eingereicht werden. Kein Querformat! Der gesamte Text und die Abbildungen sind in einem Rechteck von 17 $\mathrm{cm}$ Breite und 23,7 cm Höhe unterzubringen. Dabei sind Seitenränder ( $3 \mathrm{~cm}$ von oben und unten, $2 \mathrm{~cm}$ von links und rechts zu berücksichtigen. 


\section{Schriftart}

Das Standardzeichenformat ist Arial 13, normal, Blocksatz. Der Zeilenabstand beträgt 1,0.

\section{Experimentelles [Arial 14, fett, links]}

\section{Abbildungen und Tabellen [Arial 12, fett, kursiv, links]}

Abbildungen, Schemata, Grafiken und Tabellen müssen in den Text in geeigneter Größe eingebettet werden. Bitte beachten Sie, dass die Originalgröße auf etwa $70 \%$ reduziert wird. Chemische Strukturen müssen mit einem geeigneten Programm (vorzugsweise ACD/ChemSketch oder Isis Draw) gefertigt sein und einheitliche Größe und Form innerhalb eines Manuskripts aufweisen. Für die Beschriftung von Zeichnungen und Tabellen beachten Sie bitte die unten angeführten Beispiele.

\section{Tabellen [Arial 12, kursiv, links]}

Tab. 1. Beispiel für die Beschriftung einer Tabelle [Arial 12, Blocksatz]

\begin{tabular}{llllll}
\hline$\#$ & A $^{\mathbf{a}}$ & B & C & D & [Arial 12, fett] \\
\hline 1 & 1.2 & $2.4^{\mathrm{b}}$ & 3.6 & 4.8 & [Arial 12] \\
2 & 0.6 & 1.8 & 3.6 & 5.4 & \\
3 & 2.1 & 4.2 & 6.3 & 8.4 & \\
\multicolumn{2}{l}{${ }^{\mathrm{a}}$ Durschnitt. } & \\
&
\end{tabular}

Abbildungen [Arial 12, kursiv, links]<smiles>CN1C2CCC1CC(OC(=O)[C@H](CO)c1ccccc1)C2</smiles>

Abb. 1. Beispiel für Darstellung einer chemischen Struktur [Arial 12, Blocksatz]

\section{Nomenklatur}

Die chemische Nomenklatur muss den IUPAC Regeln folgen und solte mit einem professionellen Computerprogramm kontrolliert werden; Die botanische Nomenklatur muss in Übereinstimmung mit dem "International Code" oder "Englers Syllabus der Pflanzennamen" erfolgen.

\section{Charakterisierung neuer Substanzen}

Alle neu erhaltenen Verbindungen bedürfen einer sorgfältigen Analyse mit folgenden Verfahren: ${ }^{1} \mathrm{H}-\mathrm{NMR},{ }^{13} \mathrm{C}-\mathrm{NMR}, \mathrm{MS}$ (inkl. Fragmentierungsmuster bei EI-MS), Elementaranalyse; Schmelzpunkt für feste Substanzen. Weitere Techniken wie z. B. IR, HRMS, X-NMR, 2D NMR, Röntgenstrukturanalyse, HPLC, etc. können erforderlich sein und 
sollten - sofern verfügbar - angewandt werden. Gutachter wie Redakteure können die Einreichung der Originalspektren verlangen. Für Pflanzenextrakte sind charakteristische DC/HPLC-Chromatogramme erforderlich (fingerprint).

Fiktives Beispiel:

Farblose Kristalle FP 118-120 ${ }^{\circ} \mathrm{C}$ (wässr. Ethanol). MS ( $\left.m / z, \%\right): 202\left(\mathrm{M}^{+}, 3\right), 184(36), 73$ (100). IR (KBr), v, cm ${ }^{-1}: 1683,1645 .{ }^{1} \mathrm{H}-\mathrm{NMR}\left(500 \mathrm{MHz}, \mathrm{CDCl}_{3}, \mathrm{TMS}\right): \delta$ 8.74-8.80 (m, $2 \mathrm{H}, \mathrm{H}-3,5), 8.18\left(\mathrm{dd},{ }^{3} J_{\mathrm{H} 2, \mathrm{H} 1}=7.7 \mathrm{~Hz},{ }^{4} J_{\mathrm{H} 2, \mathrm{H} 7}=1.1 \mathrm{~Hz}, 1 \mathrm{H}, \mathrm{H} 2\right), 7.68(\mathrm{~s}, 1 \mathrm{H}, \mathrm{H}-6), \ldots$ ${ }^{13} \mathrm{C}-N M R\left(125 \mathrm{MHz}, \mathrm{DMSO}-d_{6}, \mathrm{TMS}\right): \delta 175.4(\mathrm{COOH}), 136.3(\mathrm{C}-7), 134.1\left(\mathrm{C}_{\mathrm{q}}\right), 128.0$ $(\mathrm{CH}), 127.6(\mathrm{CH}), 54.3\left(\mathrm{CH}_{2}\right), \ldots$ HRMS: Berechnet für $\mathrm{C}_{11} \mathrm{H}_{10} \mathrm{~N}_{2} \mathrm{O}_{2}$ : 202.0742. Gefunden: 202.0746. Analyse Berechnet für $\mathrm{C}_{11} \mathrm{H}_{10} \mathrm{~N}_{2} \mathrm{O}_{2}: \mathrm{C}, 65.34 ; \mathrm{H}, 4.98 ; \mathrm{N}, 13.85$. Gefunden: $\mathrm{C}$, $65.04 ; \mathrm{H}, 5.22 ; \mathrm{N}, 13.60$.

\section{Sprachkorrekturen}

Die Verantwortung für sprachlich einwandfreie Arbeiten liegt bei den Autoren. Bei Veröffentlichungen in einer anderen Sprache als der Muttersprache sind möglichst externe Institutionen zu beauftragen und die entsprechenden Referenzen im Begleitschreiben an den Redakteur mitzuteilen. Diverse Sprachinstitute sind unter www.scipharm.at/autoren verklinkt. Sci Pharm spricht jedoch ausdrücklich keine Empfehlung für eine bestimmte Firma aus und hat keinerlei finanzielle Verbindungen diesbezüglich.

\section{Ausschlusskriterien}

Sprache \& Zeitschriftenstil

Arbeiten mit sprachlichen Mängeln und Arbeiten, die nicht den Autorenrichtlinien folgen, werden nicht angenommen.

\section{Ethische Stellungnahmen}

Arbeiten ohne ausreichende Stellungnahme zu Interessenskonflikten, Menschenrechten (und Einverständniserklärung der Patienten) bzw. Tierrechten werden nicht bearbeitet.

\section{Substanzcharakterisierung}

Arbeiten ohne ausreichende analytische Untersuchung (z. B. $\left.{ }^{13} \mathrm{C}-\mathrm{NMR}\right)$ werden abgelehnt.

\section{Diverses}

Routinebestimmungen von $L_{50}$-Werten für neue Substanzen sind ethisch nicht vertretbar.

\section{Danksagung [Arial 14, fett, links]}

Kurze Danksagungen können aufgenommen werden.

\section{Zusatzmaterial}

Eine Auflistung von allenfalls vorhandenem Zusatzmaterial soll kurz gegeben und dieses beschrieben werden; z. B. Kopien der ${ }^{1} \mathrm{H}$ - und ${ }^{13} \mathrm{C}-N M R-S p e k t r e n$ der Verbindungen 1a1f, 2a und 3a-3f (Format: PDF, Größe: 1.2 MB). 


\section{Ethische Stellungnahmen der Autoren}

\section{Interessenskonflikte}

\section{Grundsatz}

Ein Interessenskonflikt besteht sobald ein Individuum (oder dessen Institution) eine finanzielle, persönliche oder berufsmäßige Beziehung zu anderen Personen oder Institutionen besitzt, die seine Entscheidungen und Handlungen beeinflussen könnte. Interessenskonflikte entstehen aus solchen Situationen unabhängig davon, ob die Entscheidung konkret oder möglicherweise beeinflusst ist.

\section{Beispiele für eine Stellungnahme}

Die Autoren bestätigen ihre Unabhängigkeit. / $A B C$ besitzt ein Patent für ... / DEF erhält als Berater ein Honorar von der Firma XYZ ...

\section{Patientenaufklärung und -einverständnis, Befürwortung Ethikkommission}

\section{Grundsatz}

Patienten haben ein Recht auf Privatsphäre, gegen das nicht verstoßen werden darf. Jegliche Information, die den Patienten identifizieren könnte (z. B. Namen, Initialen, Krankenhausnummern, etc.) dürfen nicht veröffentlicht werden, sofern dies nicht aus wissenschaftlicher Sicht erforderlich ist und der betreffende Patient (bzw. seine Eltern oder sein Vormund) seine schriftliche Zustimmung gibt.

Bei Untersuchungen von Menschen muss im Abschnitt „Experimentelles” bestätigt werden, dass die ethischen Standards der Helsinki-Deklaration von 1964 (erneuert 2000, http://www.wma.net/e/policy/b3.htm) eingehalten wurden und dass eine Zustimmung des zuständigen Ethikkomitees vorliegt.

\section{Tierrechte}

\section{Grundsatz}

Bei Tierexperimenten muss im Abschnitt „Experimentelles” bestätigt werden, dass die nationalen und internationalen ethischen Standards eingehalten wurden und dass eine Zustimmung des zuständigen Ethikkomitees vorliegt.

\section{Literatur [Arial 14, fett, links]}

Literaturverweise im Text werden fortlaufend in eckigen Klammern nummeriert z. B. [2-4] und im Abschnitt "Literatur" aufgelistet. Schriftformat ist Arial 10, normal, einzeilig. Fußbzw. Endnoten dürfen nicht verwendet werden. Die Zitierung der Literatur erfolgt in Anlehnung an den "Vancouver style" [1] wie unten dargestellt (Bücher [2], Zeitschriften $[3,4])$.

Autor: In der ersten Zeile eines Zeitschriftenzitates sind alle Autoren in der Originalreihenfolge anzugeben. Jedem Nachnamen werden die Initialen seiner Vor- bzw. Mittelnamen (max. 2) nachgestellt. Einzelne Autoren werden mittels Beistrich getrennt. Nach dem letzten Autor erfolgt ein Punkt und ein weicher Zeilenumbruch (durch gleichzeitiges Drücken der Enter- und Shifttaste) 
$\square \quad$ Titel: Der Titel wird wie im Original wiedergegeben, gefolgt von einem Punkt und einem weichen Zeilenumbruch.

$\square \quad$ Zeitschrift: Der Titel wird abgekürzt; alle Wörter beginnen mit einem Großbuchstaben; keine Punkte außer nach dem letzten Wort gefolgt von einem Leerzeichen. Danach das Erscheinungsjahr, gefolgt von einem Strichpunkt und einem Leerzeichen. Dann die Bandnummer, gefolgt von einem Doppelpunkt und eine Leerzeichen. Die Heftnummer wird bei fortlaufend nummerierten Zeitschriften nicht angegeben. Die komplette Anfangs- und Endseite werden mit einem Halbgeviertstrich (= Bindestrich, -) aber ohne Leerzeichen verbunden. Am Ende erfolgt ein Punkt und ein weicher Zeilenumbruch, um eine DOINummer hinzuzufügen, bzw. ein normaler Zeilenumbruch, um mit dem nächsten Zitat fortzufahren.

$\square \quad$ DOI-Nummer: Die DOI-Nummern werden ohne Leerzeichen eingefügt gefolgt von einem normalen Zeilenumbruch. DOI-Nummern für das komplette Literaturverzeichnis können auch auf einmal auf der Internetseite http://www.crossref.org/SimpleTextQuery zugeordnet werden.

Die einreichenden Autoren sind verantwortlich für korrekte Daten und exakte Formatierung der Literaturzitate.

[1] International Committee of Medical Journal Editors.

Uniform requirements for manuscripts submitted to biomedical journals.

http://www.icmje.org/

[2] Hänsel R, Keller K, Rimpler H, Schneider G, editors.

Passiflora.

In: Hagers Handbuch der Pharm. Praxis. 5th ed. Volume 6, Drogen P-Z.

Berlin: Springer-Verlag, 1994: 34-49.

[3] Katritzky AR, Odens $\mathrm{HH}$, Zhang S.

Novel Synthesis of 2,3-Dihydro-1,5-benzothiazepin-4(5H)-ones and 2H-1,4-Benzothiazin-3(4H)-ones. J Org Chem. 2001; 66: 6792-6796. doi:10.1021/jo0101959

[4] Koch C, Reichling J, Schneeleb J, Schnitzler P.

Inhibitory effect of essential oils against herpes simplex virus type 2 .

Phytomedicine. 2008; 15: 71-78.

doi:10.1016/j.phymed.2007.09.003 


\section{Scientia Pharmaceutica, Instructions for Authors 2010}

Scientia Pharmaceutica (www.scipharm.at), a peer reviewed journal with quarterly appearance, is published at the end of every quarter of a year. It is a medium for publication of original papers, short communications, a limited number of reviews, and papers concerning pharmaceutical practice, referring to all scientific aspects of pharmacy and related disciplines.

The journal Scientia Pharmaceutica (0036-8709) is currently indexed by Chemical Abstracts (SciFinder), Scopus, Beilstein Database, International Pharmaceutical Abstracts, Natural Product Updates, CAB Abstracts, ChemInform, Embase / Excerpta Medica, Index Pharmacus, EBSCO, and many others.

Manuscripts in German or in English may be submitted via e-mail to office@scipharm.at. Alternatively a hardcopy-submission in triplicate is possible to the Editors, addressed to Univ.-Prof. Dr. W. Kubelka, Department of Pharmacognosy, University of Vienna, Althanstraße 14, A-1090 Vienna, Austria, together with the manuscript in Microsoft Wordformat on a diskette or CD. Name, address as well as e-mail address, telephone and fax number of the corresponding author have to be mentioned on a separate sheet (cover letter). It is strongly recommended to use the latest version of the MS word template for preparing the manuscript (available at www.scipharm.at/authors). The receipt of the manuscript will be acknowledged via e-mail to the corresponding author.

Only unpublished material will be accepted. If partial results are published they have to be cited correctly and the corresponding publications have to be enclosed. The Editorial Board reserves the right to reject papers with linguistic or scientific deficiencies or lacks regarding the preparation of the manuscript. Prior to the submission of reviews, an abstract must be sent to the editorial office.

The submitted manuscripts will be peer reviewed by external reviewers guided by a managing editor. It is recommended to suggest 3-5 independent and competent reviewers in the cover letter (full contacting information including e-mail is needed). The final decision is incumbent upon the Editorial Board.

By submitting a manuscript the submitting / corresponding author agrees that he is authorized by his co-authors to enter into these arrangements and he warrants, on behalf of himself and his co-authors, that ...

the article is original, has not been formally published in any other peer-reviewed journal, is not under consideration by any other journal and does not infringe any existing copyright or any other third party rights;

he is/they are the sole author(s) of the article and have full authority to enter into this agreement and in granting rights to Österreichischer Apothkerverlag m. b. H. are not in breach of any other obligation; 
the article contains nothing that is unlawful, libelous, or which would, if published, constitute a breach of contract or of confidence or of commitment given to secrecy;

he has/they have taken due care to ensure the integrity of the article. To his/their - and currently accepted scientific - knowledge all statements contained in it purporting to be facts are true and any formula or instruction contained in the article will not, if followed accurately, cause any injury, illness or damage to the user.

the article, if accepted, will be published under the Creative Commons License 3.0 (http://creativecommons.org/licenses/by/3.0/) and is licensed to Österreichischer Apothekerverlag m. b. H. In summary, this means that the copyright stays at the author(s) and that the article is published open access. Hence, anyone will be free to copy, distribute, and display the work, to make derivative works, and to make commercial use of the work under the following conditions: The original author must be given credit (citation) and for any reuse or distribution, it must be made clear to others what the license terms of this work are. Any of these conditions can be waived if the authors give permission.

There are neither author/institution fees nor page charges. Both (online) reading and publishing is free. Information on how to order the print version can be found at www.scipharm.at/subscription.

To achieve a rapid and cost-effective publication as well as a uniform appearance of Scientia Pharmaceutica the Instructions for Authors have to be considered accurately and the electronic manuscripts in Microsoft Word format have to be ready for direct reproduction.

\section{Manuscript Checklist:}

$\square \quad$ Manuscript prepared according to the Instructions for Authors, preferably using the MS Word template?

$\square \quad$ Manuscript spellchecked and external language corrections done?

$\square \quad$ One single manuscript file in MS Word format submitted? Figures, schemes, and tables inserted into the main text and no landscape format used?

$\square \quad$ Corresponding author designated, e-mail addresses and full postal addresses given?

$\square \quad$ Full names (first, middle and last names) and affiliation of all authors given?

․ Correct style for references? Citations placed in brackets, e.g. [1, 3, 6-9]

$\square \quad$ Cover letter with all relevant information for editor: e. g. submitted or in press manuscripts, statements to competing interests, informed consent, human \& animal rights, information on used language editing service etc.?

$\square \quad$ Full contacting information to potential referees given?

The following Instructions for Authors in English are organized like a manuscript. All relevant information concerning font and format are highlighted grey. The manuscripts will be reduced to approx. $70 \%$ of original size at direct reproduction. 


\section{Title of the Manuscript [Arial Black 18, bold, center alignment]}

\section{Wolfgang A. MOZART * 1 , Erwin SCHRÖDINGER ${ }^{2}$, Gregor MENDEL ${ }^{2}$, Joseph HAYDN ${ }^{1}$, Ludwig BOLTZMANN ${ }^{2}$ [Arial 14, bold, center alignment, last names in small capitals]}

\footnotetext{
${ }^{1}$ Institution, University, Street $\mathrm{Nr}$, zip code, place, country [Arial 10, justify alignment]

${ }^{2}$ Institution, University, Street $\mathrm{Nr}$, zip code, place, country [Arial 10, justify alignment]

* Corresponding author. E-mail(s): mail@mail.com (A. Author) [Arial 10, left alignment]

Sci Pharm. 20XX; 7X: XXX-XXX doi:10.3797/scipharm.xxx

Published: $\quad$ Month $D D^{\text {th }} 2010$

Accepted: $\quad$ Month $D^{\text {th }} 2010$

Received: $\quad$ Month $D^{\text {th }} 2010$

This article is available from: http://dx.doi.org/10.3797/scipharm.xxx

(c) Author et al; licensee Österreichische Apotheker-Verlagsgesellschaft m. b. H., Vienna, Austria.

This is an Open Access article distributed under the terms of the Creative Commons Attribution License (http://creativecommons.org/licenses/by/3.0/), which permits unrestricted use, distribution, and reproduction in any medium, provided the original work is properly cited.
}

\section{Abstract [Arial 14, bold, left margin of $1 \mathrm{~cm}$ ]}

The paper's main outcome should be outlined in about one paragraph (max. 200 words). [Arial 12, justify alignment, left and right margin of $1 \mathrm{~cm}$ ]

\section{Keywords [Arial 14, bold, left alignment]}

Maximum 5 Keywords, separated by bullets $(\bullet)$. Do not duplicate title words.

\section{Introduction [Arial 14, bold, left alignment]}

The manuscripts should be divided into sections, e.g. "Abstract", "Keywords", "Introduction", "Results and Discussion", "Experimental", "Acknowledgements" (if necessary), "Supporting Information", "Ethical Statements" and "References".

\section{Results and Discussion [Arial 14, bold, left alignment]}

\section{Page format [Arial 12, bold, italic, left alignment]}

Manuscripts should be submitted on A4 paper $(21.0 \times 29.7 \mathrm{~cm})$, portrait. Landscape format must not be used! All graphics and text must be placed in an image area $17 \mathrm{~cm}$ wide and $23.7 \mathrm{~cm}$ high. This image area should be created by setting a top and bottom margin of 3 $\mathrm{cm}$, a left and right margin of $2 \mathrm{~cm}$.

\section{Font}

The letter format is Arial 12, normal, justify alignment, line space is 1.0. 


\section{Experimental [Arial 14, bold, left alignment]}

\section{Figures and tables [Arial 12, bold, italic, left alignment]}

Figures, schemes, graphs and tables must be inserted in the text appropriately in a suitable size. Please note that the original size will be reduced to approx. $70 \%$ during printing. Chemical structures should be drawn with a suitable drawing program (preferably ACD/ChemSketch or Isis Draw). For the inscription of figures and tables see examples.

Tables [Arial 12, italic, left alignment]

Tab. 1. Description [Arial 12, left alignment]

\begin{tabular}{llllll}
\hline$\#$ & $\mathbf{A}^{\mathbf{a}}$ & $\mathbf{B}$ & $\mathbf{C}$ & $\mathbf{D}$ & [Arial 12, bold] \\
\hline 1 & 1.2 & $2.4^{\mathrm{b}}$ & 3.6 & 4.8 & [Arial 12] \\
2 & 0.6 & 1.8 & 3.6 & 5.4 & \\
3 & 2.1 & 4.2 & 6.3 & 8.4 & \\
\hline \multicolumn{2}{c}{ mean of 3 runs. $^{\mathrm{b}}$ special note. } & [Arial 10]
\end{tabular}

Figures [Arial 12, italic, left alignment]<smiles>CN1C2CCC1CC(OC(=O)[C@H](CO)c1ccccc1)C2</smiles>

Fig. 1. Example for the chemical structure of a compound [Arial 12, left alignment]

\section{Nomenclature}

Chemical nomenclature should follow the rules of the IUPAC and should be proved by professional computer software; botanical nomenclature must be in agreement with the corresponding "International Code" or Englers "Syllabus der Pflanzennamen".

\section{Characterization of new compounds / plant extracts}

Typically, all new compounds need a detailed analysis with the following state-of-the-art techniques: ${ }^{1} \mathrm{H}$ NMR, ${ }^{13} \mathrm{C}$ NMR, MS (including fragmentation pattern for EI MS), elemental analysis; MP for solid compounds. Additional techniques such as IR, hrMS, X NMR, 2D NMR, X-Ray, HPLC, etc. may be required and all available data should be given whenever possible. The referees/editors may request the submission of the original spectra. TLC/HPLC fingerprint for plant extracts and fractions are required.

Fictitious Example:

Colorless crystals of $\mathrm{mp} 118-120^{\circ} \mathrm{C}$ (aqu. ethanol). MS $(\mathrm{m} / \mathrm{z}, \%): 202\left(\mathrm{M}^{+}, 3\right), 184(36), 73$ (100). IR (KBr), v, cm ${ }^{-1}: 1683,1645 .{ }^{1} \mathrm{H}$ NMR (500 MHz, CDCl 3 , TMS): $\delta$ 8.74-8.80 (m, 
$2 \mathrm{H}, \mathrm{H}-3,5), 8.18\left(\mathrm{dd},{ }^{3} J_{\mathrm{H} 2, \mathrm{H} 1}=7.7 \mathrm{~Hz},{ }^{4} \mathrm{~J}_{\mathrm{H} 2, \mathrm{H} 7}=1.1 \mathrm{~Hz}, 1 \mathrm{H}, \mathrm{H} 2\right), 7.68(\mathrm{~s}, 1 \mathrm{H}, \mathrm{H}-6), \ldots{ }^{13} \mathrm{C}$ NMR (125 MHz, DMSO-d $d_{6}$ TMS): $\delta 175.4(\mathrm{COOH}), 136.3(\mathrm{C}-7), 134.1\left(\mathrm{C}_{\mathrm{q}}\right), 128.0(\mathrm{CH})$, $127.6(\mathrm{CH}), 54.3\left(\mathrm{CH}_{2}\right), \ldots$ HRMS: Calcd. for $\mathrm{C}_{11} \mathrm{H}_{10} \mathrm{~N}_{2} \mathrm{O}_{2}: 202.0742$. Found: 202.0746 . Anal. Calcd. for $\mathrm{C}_{11} \mathrm{H}_{10} \mathrm{~N}_{2} \mathrm{O}_{2}$ : C, 65.34; $\mathrm{H}, 4.98 ; \mathrm{N}, 13.85$. Found: $\mathrm{C}, 65.04 ; \mathrm{H}, 5.22 ; \mathrm{N}$, 13.60.

\section{Language corrections}

It is the responsibility of the authors who publish in a language other than their native one to ensure correct language usage by an external proof reading institution. Papers with poor language will be rejected! In the cover letter the used organization together with the corresponding job number should be given. Editing certificates such as those from American Journal Experts (20-digit certification code must be provided) are accepted as proof for sufficient language quality of the submitted paper. Exemplary links to some companies specialized in proof reading of scientific papers can be found at www.scipharm.at/authors. However, it should be noted that Sci Pharm does not recommend a specific organization nor does have any financial relation to one of them.

\section{Criteria for immediate rejection}

\section{Language \& journal style}

Papers with poor language or papers lacking the journal's formal style as described in these instructions are not acceptable.

\section{Ethical guidelines}

Papers from authors who do not unambiguously clarify their competing interests or who do not provide sufficient information on human rights (and informed consent) as well as on animal rights will not be processed.

\section{Characterization of compounds}

Manuscripts will be rejected if sufficient analytical data (e. g. ${ }^{13} \mathrm{C}$ NMR) are not provided.

\section{Miscellaneous}

Routinely determined $L D_{50}$ data for new compounds are not ethically acceptable.

\section{Acknowledgement [Arial 14, bold, left alignment]}

Short acknowledgements may be mentioned.

\section{Supporting Information}

The content of any supplementary material (if provided) should be described. e. g. Copies of ${ }^{1} \mathrm{H}$ and ${ }^{13} \mathrm{C}$ NMR spectra of compounds 1a-1f, 2a and 3a-3f (Format: PDF, Seize: 1.2 MB). 


\section{Ethical statement(s)}

\section{Competing interests}

Competing interests policy

A competing interest exists when an individual (or the individual's institution) has financial, personal or professional relationships with other persons or institutions that could unduly bias his or her actions or judgments. Competing interests may arise of those relationships, irrespective of whether the judgment is actually affected or only potentially.

\section{Example statement}

e. g. The authors declare no conflict of interest. / ABC holds a patent on ... / DEF is a consultant of the company XYZ ...

\section{Informed Consent \& Ethical Approvals (if applicable)}

Informed consent policy

Patients have a right to privacy that should not be infringed without informed consent. Identifying information, including patients' names, initials, or hospital numbers, should not be published in written descriptions, photographs, and pedigrees unless the information is essential for scientific purposes and the patient (or parent or guardian) gives written informed consent for publication.

\section{Human rights policy}

Investigations with human subjects must state in the experimental section that the research followed the ethical standards formulated in the Helsinki Declaration of 1964, revised in 2000 (http://www.wma.net/e/policy/b3.htm), and was approved by the institutional human experimentation committee or equivalent. Any doubt about the ethical suitability of the human procedures used will cause the immediate rejection of the paper by the editors.

\section{Animal Rights (if applicable)}

Animal rights policy

Investigations with animals must state in the experimental section that the research followed the (inter)national ethical standards for the care and use of laboratory animals and was approved by the institutional animal experimentation committee or equivalent. Any doubt about the ethical suitability of the animal procedures used will cause the immediate rejection of the paper by the editors.

\section{References [Arial 14, bold, left alignment]}

References appearing in the text must be numbered continuously in brackets, e.g. [2-4] and listed in the section "References". Font is Arial 10, normal, left assignment. Footnotes or endnotes function of MS Word must not be used! References must be cited similarly to the "Vancouver style" [1] as shown below (books [2], journals [3, 4]). As far as possible, doi-numbers should be given in a separate line. 
$\square \quad$ Author: In the first line of each journal citation, all authors are given in the order they appear in the original text. The capitalized surname (family or last name) is given first and - after inserting a space - the given (first) names and middle names are converted to initials, for a maximum of two initials following each surname. Separate author names from each other by a comma and a space; end the author information with a period. Insert a soft-return (by pressing both the shift and enter key simultaneously) to start the title line.

$\square \quad$ Title: Enter the title of an article as it appears in the original publication. End the title with a period and insert a soft-return to start the journal line.

$\square \quad J o u r n a l:$ Abbreviate the journal's name, capitalize all words and abbreviations, do not use periods except after the last word which is followed by a period and a space. Insert the publication year followed by a semicolon and a space. Insert the volume followed by a colon and a space. Do not give issue numbers. Insert both the article's first and last page, separated by an en-dash (-) without any spaces. End the page number with a period. Insert a soft-return for entering the doi number (if available) or insert a hard-return to continue with a new citation.

$\square \quad$ Doi-number: Insert the doi-number without any spaces. End with a hard-return to continue with a new citation. Doi-numbers can be easily assigned by using the free web-service at http://www.crossref.org/SimpleTextQuery (just copy your reference list into the box and press 'submit').

It's the sole responsibility of the submitting authors to provide exactly formatted and correct citations!

[1] International Committee of Medical Journal Editors.

Uniform requirements for manuscripts submitted to biomedical journals.

http://www.icmje.org/

[2] Hänsel R, Keller K, Rimpler H, Schneider G, editors.

Passiflora.

In: Hagers Handbuch der Pharm. Praxis. 5th ed. Volume 6, Drogen P-Z.

Berlin: Springer-Verlag, 1994: 34-49.

[3] Katritzky AR, Odens HH, Zhang S.

Novel Synthesis of 2,3-Dihydro-1,5-benzothiazepin-4(5H)-ones and 2H-1,4-Benzothiazin-3(4H)-ones. J Org Chem. 2001; 66: 6792-6796.

doi:10.1021/jo0101959

[4] Koch C, Reichling J, Schneeleb J, Schnitzler P.

Inhibitory effect of essential oils against herpes simplex virus type 2.

Phytomedicine. 2008; 15: 71-78.

doi:10.1016/j.phymed.2007.09.003 